Abstracta Iranica Abstracta Iranica

Revue bibliographique pour le domaine irano-aryen

Volume 29 | 2008

Comptes rendus des publications de 2006

\title{
Catalog monet Čača III-VIII vv. Tachkent, FAN, 2006, 325 p. [Catalogue des monnaies du Čač III ${ }^{\mathrm{e}}-\mathrm{VIII}^{\mathrm{e}} \mathrm{s}$.]
}

\section{Étienne de La Vaissière}

\section{Q OpenEdition \\ 12 Journals}

\section{Édition électronique}

URL : http://journals.openedition.org/abstractairanica/25562

DOI : 10.4000/abstractairanica.25562

ISSN : 1961-960X

Éditeur :

CNRS (UMR 7528 Mondes iraniens et indiens), Éditions de l'IFRI

\section{Édition imprimée}

Date de publication : 15 mai 2008

ISSN : 0240-8910

\section{Référence électronique}

Étienne de La Vaissière, «Catalog monet Čača III-VIII vv. Tachkent, FAN, 2006, 325 p. [Catalogue des monnaies du Čač IIIe-VIII s.] », Abstracta Iranica [En ligne], Volume 29 | 2008, document 60, mis en ligne le 15 septembre 2008, consulté le 26 septembre 2020. URL : http://journals.openedition.org/ abstractairanica/25562 ; DOI : https://doi.org/10.4000/abstractairanica.25562

Ce document a été généré automatiquement le 26 septembre 2020.

Tous droits réservés 


\title{
Catalog monet Čača III-VIII vv. Tachkent, FAN, 2006, 325 p. [Catalogue des monnaies du Čač III ${ }^{\mathrm{e}}$ VIII $^{\mathrm{e}}$ s.]
}

\author{
Étienne de La Vaissière
}

Ce catalogue des monnaies du Čač utilise un corpus de deux mille pièces, dont trois cents sont décrites dans le catalogue, et forme la tentative de présentation systématique des monnaies pré-islamiques du Čač la plus complète à ce jour. La présentation est soignée et les reproductions, photos et dessins, de bonne qualité. Il est de plus entièrement bilingue russe-anglais. Les AA. situent la naissance du monnayage $\mathrm{au} \mathrm{III}^{\mathrm{e}} \mathrm{s}$. de n.è. et l'étudient jusqu'au VIII ${ }^{\mathrm{e}} \mathrm{s}$. Ils distinguent neuf groupes de monnaies regroupant trente-six types différents, certains inédits. Leur classification s'inspire de celle établie par E. Rtveladzé (Istorija i numismatika Čača, 2006, c.r. $n^{\circ}$ 59) avec des modifications importantes. Les AA. semblent pris entre deux feux pour les monnaies des $\mathrm{VI}^{\mathrm{e}}-\mathrm{VIII}{ }^{\mathrm{e}} \mathrm{s}$. : d'une part les lectures iranisantes des légendes proposées par E. Rtveladzé (et V. Livšic), et d'autre part les lectures turquisantes proposées par G. Babayarov. Ils s'abstiennent généralement de trancher et donnent toutes les lectures proposées ainsi que des dessins soigneux des légendes. Mais ce système donne lieu à un étrange appendice (pp. 294-7), signé E. Rtveladzé qui, profitant de son statut d'éditeur, indique ses principaux points de désaccord avec les auteurs. 
INDEX

Thèmes : 3.1. Est de l'Iran

\section{AUTEURS}

ÉTIENNE DE LA VAISSIĖRE

EPHE - Paris 